\title{
CZY WŁADZE KOMUNISTYCZNE PLANOWAŁY USUNACĆ ADMINISTRATORÓW APOSTOLSKICH Z ZIEM ZACHODNICH I PÓŁNOCNYCH JUŻ LATEM 1950 ROKU? HIPOTEZA WCZEŚNIEJSZEGO TERMINU AKCJI „B”
}

\author{
Karol Kubicki \\ Uniwersytet Papieski Jana Pawła II w Krakowie
}

\begin{abstract}
DID THE POLISH COMMUNIST AUTHORITIES TRY TO REMOVE APOSTOLIC ADMINISTRATORS FROM THE RECOVERED TERRITORIES ALREADY IN THE SUMMER OF 1950? THE HYPOTHESIS OF THE EARLIER DATE OF OPERATION B
\end{abstract}

In 1945, A. Hlond, the Primate of Poland authorized by the Pope, created five temporary apostolic administrations on the so-called Recovered Territories, which were to operate until new dioceses were founded by the Holy See. On the $26^{\text {th }}$ January 1951 the communist authorities removed the apostolic administrators and replaced them with illegally elected capitular vicars. In this way, for the first time in Poland, the government took control over dioceses using a method that had already been applied in Czechoslovakia and Hungary. It involved replacing legal bishops with temporary administrators willing to cooperate with the Polish government. The decision was taken by the top authorities of communist Poland and its implementation, referred to as "Operation B," was to be executed by the Ministry of Public Security. The steps taken earlier by the communist authorities could indicate that initially there had already been plans to remove the apostolic administrators in July 1950.

Key words: Church in the Polish People's Republic, Recovered Territories, apostolic administrator, capitular vicar, Operation B.

Słowa kluczowe: Kościół w PRL, Ziemie Odzyskane, administrator apostolski, wikariusz kapitulny, akcja B.

W antykościelnej polityce polskich władz komunistycznych styczeń 1951 roku stanowi jeden z punktów wyznaczających jej intensywność, zarówno poprzez 
nagromadzenie działań represyjnych, jak i ich ukierunkowanie bezpośrednio na hierarchów Kościoła. 20 stycznia aresztowano biskupa kieleckiego Czesława Kaczmarka, zaś sześć dni później usunięto pięciu administratorów apostolskich, pełniących od 1945 roku funkcje ordynariuszy na terenach tzw. Ziem Odzyskanych ${ }^{1}$. O ile w Kielcach na pierwszy plan wysunięto sprawę podważających autorytet Kościoła oskarżeń personalnych i rozwinięto z niej propagandowy lincz na przedstawicielu polskiego Episkopatu, to w przypadku Ziem Zachodnich i Północnych aspekt represji indywidualnych ustąpił miejsca działaniom zmierzającym do podporządkowania struktur organizacyjno-administracyjnych Kościoła państwowym czynnikom decyzyjnym.

Zgodnie z decyzją Biura Politycznego KC PZPR ${ }^{2}$ oraz z instrukcją opracowaną w Departamencie V MBP ${ }^{3}$ w piątek, 26 stycznia 1951 roku, w godzinach rannych do siedzib administratorów apostolskich i budynków kurii w Opolu, Wrocławiu, Gorzowie Wielkopolskim, Gdańsku i Olsztynie wkroczyli w towarzystwie funkcjonariuszy UB urzędnicy referatów ds. wyznań. Przedsięwzięciu nadano kryptonim akcja „B”. Administratorom apostolskim ${ }^{4}$ oraz ich wikariuszom generalnym przedstawiono kolejno do podpisania oświadczenia w trzech wariantach, a następnie zmuszono do opuszczenia terenu tzw. Ziem Odzyskanych. Jeszcze tego samego dnia, zgodnie z wytycznymi MBP, przeprowadzono w poszczególnych administracjach kontrolowane przez funkcjonariuszy państwowych wybory wikariuszy kapitulnych, co było właściwym meritum akcji ukierunkowanej nie tyle na pozbycie się osób administratorów, ile na przejęcie kontroli nad organizacją kościelną tych terenów poprzez uległych władzom państwowym zarządców 5 .

Bez wątpienia tzw. Ziemie Odzyskane stały się dla komunistycznych władz poligonem doświadczalnym wypróbowania konkretnego zabiegu ingerującego $\mathrm{w}$ autonomię Kościoła: odsunięcia przemocą prawomocnego ordynariusza i narzucenia

1 Dekretami datowanymi na 15 sierpnia 1945 r. prymas Polski A. Hlond, na mocy specjalnych pełnomocnictw otrzymanych od papieża Piusa XII, mianował administratorami apostolskimi: ks. B. Kominka w Opolu, ks. K. Milika we Wrocławiu, ks. E. Nowickiego w Gorzowie Wielkopolskim, ks. A. Wronkę w Gdańsku oraz ks. T. Benscha w Olsztynie. Choć nie posiadali sakry biskupiej, przysługiwały im prawa i obowiązki biskupów rezydencjalnych, wchodzili także w skład Konferencji Episkopatu Polski.

2 Archiwum Akt Nowych w Warszawie (AAN), Komitet Centralny Polskiej Zjednoczonej Partii Robotniczej (KC PZPR), sygn. V/16, Protokół nr 49 z posiedzenia BP KC PZPR, Warszawa, 20 stycznia 1951 r., k. 30.

3 Oddziałowe Biuro Udostępniania i Archiwizacji Dokumentów IPN w Katowicach, sygn. S38/02/Zk, k. 1526-1528 oraz Biuro Udostępniania i Archiwizacji Dokumentów IPN w Warszawie (IPN BU), sygn. 01332/4, k. 220-222. Instrukcja ta doczekała się także edycji źródłowej: Instrukcje, wytyczne, okólniki dyrektor Departamentu V MBP dotyczace działań przeciwko Kościołowi katolickiemu w latach 19451953, wybór i oprac. A. Dziurok, J. Marecki, F. Musiał, Kraków-Katowice 2012, s. 242-245, przy czym nie podano, że była ona publikowana wcześniej w opracowaniu: A. Sitek, Porwali Go z miejsca i wyrzucili $($ Lk 4, 29). Trzy wypędzenia, Opole 2004, s. 7-9.

4 Jedynie ks. Nowickiego nie zastano w Gorzowie Wielkopolskim, funkcjonariusze UB odbyli z nim rozmowę kilka dni później (przed 31 stycznia) w Poznaniu.

5 Kolegia konsultorów wybrały na wikariuszy kapitulnych: w Gorzowie Wielkopolskim ks. T. Załuczkowskiego, w Olsztynie ks. W. Zinka, w Gdańsku ks. J. Cymanowskiego, w Opolu ks. E. Kobierzyckiego, zaś we Wrocławiu wyboru ks. K. Lagosza dokonał w imieniu kapituły katedralnej ks. F. Niedźbała. 
uległego zarządcy diecezji. W przypadku administracji apostolskich na Ziemiach Zachodnich i Północnych próba ta się powiodła ${ }^{6}$. Dlatego też władze państwowe odważyły się zastosować podobne posunięcia względem biskupów „normalnych” diecezji (Katowice ${ }^{7}, \mathrm{Kraków}^{8}$, nieudane próby w Sandomierzu ${ }^{9}$ ), stosując „metodę «nasadzania wikariuszy kapitulnych»"10.

W ten sposób próbowano dążyć do przejęcia wewnętrznej kontroli nad danymi diecezjami. Schemat takiego działania, wykorzystujący instytucję wikariusza kapitulnego wybieranego przez posłuszną kapitułę (lub radę konsultorów), nie był „wynalazkiem" polskich komunistów. Podobne zabiegi stosowane były na większą skalę także w innych państwach bloku wschodniego, przede wszystkim na Węgrzech i w Czechosłowacji, stąd określano je mianem „modelu czechosłowackiego" „czechizacją Kościoła”12. Po usunięciu administratorów apostolskich i po wypadkach w Katowicach i Krakowie prymas Stefan Wyszyński „,nie zamierzał dopuścić do sytuacji, w której wszystkie diecezje będą rządzone nie przez biskupów ordynariuszy, lecz przez wikariuszy kapitulnych, wybieranych pod naciskiem lub w uzgodnieniu z rządem"13. Na tym tle widać wyraźnie przełomowe w realizacji antykościelnej polityki państwa znaczenie wydarzeń z 26 stycznia 1951 roku $^{14}$.

6 Usunięcie bp. Cz. Kaczmarka doprowadziło już 23 stycznia 1951 r. do „próby sił” między Rządem a Episkopatem w kwestii decyzji personalnych odnośnie do powierzenia zarządu diecezją kielecką, zob. J. Śledzianowski, Ksiadz Czesław Kaczmarek biskup kielecki 1895-1963, Kielce 1991, s. 128; por. R. Gryz, Państwo a Kościót w Polsce 1945-1956 na przykładzie województwa kieleckiego, Kraków 1999, s. 262; J. Żurek, Ruch „księży patriotów” $w$ województwie katowickim w latach 1949-1956, Warszawa-Katowice 2009, s. 175.

7 Po usunięciu z diecezji katowickiej bp. S. Adamskiego i jego biskupów pomocniczych władze odrzuciły czterech kolejnych kandydatów Episkopatu na stanowisko wikariusza kapitulnego. Pod naciskiem funkcjonariuszy UB kapituła wybrała na wikariusza ks. F. Bednorza, związanego z ruchem „księży patriotów", któremu prymas S. Wyszyński ostatecznie post factum udzielił jurysdykcji kanonicznej, sanując nieważnie dokonany wybór. A. Graje wski, Wygnanie, Katowice 1995, s. 111-121; A. Du dek, Państwo i Kościót w Polsce 1945-1970, Kraków 1995, s. 30-31.

8 Po internowaniu abp. E. Baziaka i bp. S. Rosponda udało się prymasowi Wyszyńskiemu uzyskać zgodę władz, by rządy w archidiecezji krakowskiej jako wikariusz kapitulny objął bp F. Jop. A. Mic ew ski, Kościót - państwo, Warszawa 1994, s. 29.

9 B. Stanaszek, ,Wrogo ustosunkowany do naszego państwa”. Biskup Piotr Golębiowski w dokumentach komunistycznej bezpieki $i$ władz wyznaniowych, Sandomierz 2006, s. 23, przypis 27; idem, Usunać biskupa! Władze PRL wobec ordynariusza diecezji sandomierskiej Jana Kantego Lorka, Sandomierz 2004, s. 93, przypis 266.

10 A. Dziurok, Wstęp [w:] Metody pracy operacyjnej aparatu bezpieczeństwa wobec Kościołów i zwiazków wyznaniowych 1945-1989, red. A. Dziu rok, Warszawa 2004, s. 41.

11 A. Grajewski, Chronologia i historyczne uwarunkowania represji wobec duchowieństwa katolickiego w krajach Europy Środkowej [w:] Represje wobec duchowieństwa Kościołów chrześcijańskich w okresie stalinowskim w krajach byłego bloku wschodniego, red. J. Myszor, A. Dziurok, Katowice 2004, s. 24.

12 K. Gruczyński, Biskup Michat Klepacz 1893-1967, Łódź 1993, s. 271.

13 A. Micewski, Kościót..., s. 29.

14 Zabieg przejmowania kontroli nad diecezjami przy wykorzystaniu instytucji wikariusza kapitulnego okaże się metodą, której stosowanie będzie rozważane przez aparat bezpieczeństwa także po $1956 \mathrm{r}$. „Aresztowanie, izolowanie lub niewpuszczenie do kraju biskupa Tokarczuka zmusiłoby hierarchię do wyboru tymczasowego rządcy diecezji [...] Kilka tego rodzaju faktów miało miejsce w Polsce, m.in. 
Uniemożliwienie administratorom apostolskim dalszego sprawowania ich funkcji było więc pierwszym akordem gry rozłożonej w czasie i ukierunkowanej na przejęcie kontroli nad organizacją Kościoła na tzw. Ziemiach Odzyskanych. Po wyborze wikariuszy kapitulnych kolejnymi odsłonami scenariusza założonego przez władze komunistyczne było dwutorowe działanie, $\mathrm{z}$ jednej strony mające na celu stworzenie wrażenia, że zmiana zarządu kościelnego stabilizuje sytuację Kościoła polskiego na ziemiach poniemieckich i poprawia warunki bytowe duchowieństwa (mianowanie stałych proboszczów, ulgi podatkowe), z drugiej zaś strony polegające na dalszej destabilizacji struktur kościelnych (inwigilacja pracowników kurii, członków rad konsultorów, rozbudowa sieci agenturalnej, wzmacnianie struktur tzw. „księży patriotów”) w celu przejęcia pełnej kontroli nad zarządem kościelnym poszczególnych administracji.

Najdalej posunięte zapędy realizacji tych planów widać na przykładzie administracji apostolskiej Dolnego Śląska. Stymulowane przez czynniki państwowe działania tamtejszego wikariusza kapitulnego, księdza Kazimierza Lagosza, zmierzające m.in. do zmiany statutów reaktywowanej kapituły katedralnej, tak by mogła dokonywać wyboru biskupa, oraz plany włączenia administracji opolskiej i gorzowskiej do archidiecezji wrocławskiej ${ }^{15}$ wskazywały, że Wrocław miał stać się polem eksperymentalnym, na którym po raz pierwszy w Polsce miano doprowadzić do zerwania struktur kościelnych z Watykanem poprzez dokonanie wyboru biskupa przez kapitułę i utworzenie „samodzielnej diecezji”, obejmującej teren trzech administracji apostolskich $^{16}$.

[...] w $1951 \mathrm{r}$. W każdym przypadku wybierani byli tymczasowi rządcy diecezji na statusie wikariusza kapitulnego [...]. W 1951 r. na ziemiach zachodnich zainstalowani zostali w ten sposób tymczasowi ordynariusze lojalni wobec władz". Informacja Dep. IV MSW dla KC PZPR dot. możliwości usunięcia bp. Tokarczuka ze stanowiska ordynariusza diecezji przemyskiej, Warszawa, 1 lutego $1971 \mathrm{r}$. [w:] Metody pracy operacyjnej..., s. 435.

15 IPN BU, sygn. 01283/790, Odpis z korespondencji prymasa Wyszyńskiego z ks. Lagoszem, [1953 r.], k. 32; W. Szetelnicki, Kapituła metropolitalna we Wrocławiu w latach 1952-1993, Wrocław 1994, s. 42-47; J. Kopiec, Wrocławski epizod w życiu biskupa Henryka Grzondziela w latach 1945-1953 [w:] Ludzie wrocławskiego Kościoła po II wojnie światowej, red. I. Dec, K. Matwijowski, J. Pater, Wrocław 2005, s. 50; S. Wyszyński, Pro memoria. Zapiski z lat 1948-1949 i 1952-1953, Warszawa 2007, s. 494, 500, 509. W rozmowie z prymasem 9 maja 1953 r. ks. Lagosz „zaklinał się »na trumnę swej matki«, że jest to jego własna inicjatywa, że w tej sprawie nie prowadził żadnej rozmowy z nikim, jakkolwiek wie o zamiarach Rządu". Ibidem, s. 512. Ks. A. Mencel wspomina o propozycji otrzymanej od ks. Lagosza, by zostać jego wikariuszem generalnym z siedzibą w Opolu. A. Hanich, Likwidacja ,stanu tymczasowości administracji kościelnej” na Śląsku Opolskim przez władze komunistyczne w 1951 r., „Forum Duszpasterskie. Biuletyn Pastoralny" 2003, nr 52, s. 52. W swoich prywatnych notatkach A. Bida snuł plany przywrócenia wielkiej archidiecezji wrocławskiej, która wchłonęłaby ordynariaty opolski i gorzowski - „byłoby to zlikwidowanie tymczasowości” [!]. AAN, Akta A. Bidy, sygn. 484/13, Notatki A. Bidy, [Warszawa, b.d.], k. 123.

16 J. Swastek, Rzadcy archidiecezji wrocławskiej w latach 1945-1995, Wrocław 1998, s. 58-59; por. J. Kopiec, Kościót katolicki na Ślasku Opolskim w totalitarnym państwie (1945-1989) [w:] Kościót opolski w PRL, red. M. Worbs, Opole 2007, s. 36. Inny plan reorganizacji struktur Kościoła na tzw. Ziemiach Odzyskanych zawierał m.in. następujące postulaty: „diecezja warmińska winna mieć swoją stolicę we Fromborku, miejscu urodzenia [!] Kopernika, a nie w przypadkowo obranym Olsztynie"; powiększenie terytorialne diecezji gdańskiej i podporządkowanie jej, jako metropolii, diecezji warmińskiej 
By utrzymać kanoniczność rządów na Ziemiach Zachodnich i jednocześnie zabezpieczyć się przed kolejnymi próbami odseparowania tamtejszych struktur Kościoła od łączności z prymasem i Rzymem, Episkopat podejmował działania mające na celu zaspokajanie, w granicach posiadanych przez prymasa pełnomocnictw, propagandowych postulatów wysuwanych przez stronę rządową. Stąd wynikało doraźne działanie strony kościelnej, polegające przede wszystkim na sanowaniu wyborów wikariuszy kapitulnych bądź wyposażaniu ich w jurysdykcję wikariuszy generalnych prymasa Polski.

Zagadnieniem priorytetowym, a jednocześnie najbardziej problemowym, pozostaje odtworzenie genezy decyzji o usunięciu administratorów apostolskich, a raczej całego planu stopniowego przejęcia kontroli nad zarządzanym przez nich Kościołem. Kwestia stosunku Episkopatu do polskiej przynależności tzw. Ziem Odzyskanych i utworzenia na nich stałych diecezji stawiana była przez stronę rządową od początku rozmów Komisji Mieszanej. W rządowych Tezach z 23 września 1949 roku postulat ten przybrał formę zapisu w swojej istocie bardzo zbliżoną do ostatecznej wersji punktu trzeciego podpisanego w kwietniu 1950 roku Porozumienia ${ }^{17}$.

O ile pierwsza sprawa, a więc wyrażenie publicznej akceptacji przesunięcia granicy na zachód i polskich praw do Ziem Zachodnich i Północnych, nie budziła sprzeciwu strony kościelnej, o tyle drugi element tego punktu, czyli doprowadzenie do reorganizacji na tych terenach struktury diecezjalnej i utworzenie nowych diecezji z polskimi biskupami, wykraczał poza kompetencje nie tylko Episkopatu, ale i specjalnych pełnomocnictw udzielonych przez papieża prymasowi Polski. Z tego względu strona kościelna dążyła do takiego sformułowania punktu dotyczącego tzw. Ziem Odzyskanych, by nie nakładał on na Episkopat niemożliwych do wypełnienia warunków, a miał jak najbardziej charakter deklaratywnej intencji. Szczególnie kardynał Adam Stefan Sapieha wykazywał ostrożność przed formułowaniem jakichkolwiek zobowiązań Episkopatu w tej kwestii, proponując, by punkt dotyczący administracji kościelnej na terenach poniemieckich ujęty był możliwie najogólniej, np. „by sprawy kościelne na Ziemiach Odzyskanych były jak najrychlej uregulowane"18.

Sprawa uregulowania administracji kościelnej na Ziemiach Zachodnich służyła nie tylko interesom polskiej racji stanu, ale także wynikała z podstawowych potrzeb duszpasterskich. Dlatego też punkt dotyczący niesprecyzowanej bliżej formy pośredniczenia Episkopatu w kwestii przyspieszenia mianowania przez Stolicę Apostolską stałych ordynariuszy na tym terenie nie budził większych zastrzeżeń negocjatorów reprezentujących stronę kościelną. Ostatecznie więc przyjęli oni, wbrew metropolicie krakowskiemu, brzmienie tego punktu w wersji zbliżonej do projektu rządowego - mianowicie, że Episkopat w sprawie mianowania stałych

\footnotetext{
i gorzowskiej; „dla potwierdzenia zaufania do dokonanej stabilizacji diecezję katowicką należy włączyć do metropolii wrocławskiej”. AAN, Urząd ds. Wyznań (UdsW), sygn. 8/1, Notatka [„Słowa Powszechnego"], Warszawa, 15 lutego 1951 r., k. 4.

17 AAN, KC PZPR, sygn. 237/V/162, Tezy do rozmów z przedstawicielami Episkopatu, Warszawa, 23 września 1949 r., k. 33.

18 List kard. Sapiehy do bp. Choromańskiego, Kraków, 12 listopada 1949 r., cyt. za: J. Żaryn, Kościót a wtadza w Polsce (1945-1950), Warszawa 1997, s. 253.
} 
ordynariuszy „Zwróci się z prośbą do Stolicy Apostolskiej”"19. Owo zwrócenie się „z prośbą do Stolicy Apostolskiej” strona kościelna wyraźnie akcentowała, przypominając, że kwestia jakichkolwiek zmian w strukturze administracji kościelnej leży tylko i wyłącznie w gestii samego papieża. Jednocześnie, jak wyjaśniał prymas Wyszyński w liście do podsekretarza stanu Stolicy Apostolskiej prałata Domenico Tardiniego, ,ustępstwo Biskupów, wyrażone w punkcie trzecim deklaracji” usprawiedliwione było dokonanym już exodusem ludności polskiej z utraconych Kresów na tereny poniemieckie: „los Narodu polskiego wysiedlonego ze wschodu na zachód, zagrożonego ponowną reemigracją byłby [...] okrutny i nieludzki”20.

W podpisanym więc 14 kwietnia 1950 roku Porozumieniu między Rządem i Episkopatem w punkcie trzecim kwestia polskiej administracji kościelnej terenów poniemieckich została oficjalnie ujęta $\mathrm{w}$ ramy zasad modus vivendi, choć będzie różnie interpretowana przez obie strony. Bez wątpienia jednak punkt trzeci Porozumienia był ruchem wygranym dla strony państwowej, która zyskiwała odtąd w planowanym (?) konflikcie wokół zarządu kościelnego tzw. Ziem Odzyskanych środek nacisku w postaci jednostronnej interpretacji parafowanego punktu, gotowej do wykorzystania w odpowiednim czasie. Pytaniem, które warto postawić, jest pytanie właśnie o ten „odpowiedni” dla władz komunistycznych czas.

Podpisanie Porozumienia oczywiście nie oznaczało zainicjowania nowej polityki władz wobec Kościoła, ale wobec trudności w precyzyjnym określeniu momentu narodzin planu odśrodkowej destrukcji Kościoła na Ziemiach Zachodnich, „roboczo”, dla uchwycenia problemu, przyjąć można czas pomiędzy kwietniem 1950 (podpisanie Porozumienia) a styczniem 1951 roku (usunięcie administratorów apostolskich), niejako w myśl archeologicznej zasady uprzywilejowania warstwy będącej bezpośrednią otuliną chronologiczną wydarzenia, za okres, w którym zapadły decyzje o terminie jego realizacji.

Władze w rzeczywistości zdawały sobie sprawę, że punkt trzeci w swoim głównym brzmieniu pozostanie martwą literą, gdyż Episkopat nie ma wpływu na zależną tylko od papieża decyzję co do stałych ordynariatów na tzw. Ziemiach Odzyskanych, a Stolica Apostolska nie podejmie w tej kwestii żadnej decyzji do czasu ostatecznego unormowania granicy polsko-niemieckiej. Potwierdziła to zresztą negatywna reakcja Stolicy Apostolskiej na wiadomość o podpisaniu przez polski Kościół Porozumienia z władzami komunistycznymi, którego właśnie punkt trzeci przyprawił Piusa XII, jak donosiła włoska prasa, o „zawrót głowy”21. Papież co najmniej uważał, że „wypowie-

19 AAN, KC PZPR, sygn. 237/V/162, Propozycje przedstawicieli Episkopatu w rozmowach z przedstawicielami Rządu, Warszawa, 4 listopada 1949 r., k. 43; Porozumienie między przedstawicielami Rządu RP i Episkopatu polskiego, Warszawa, 14 kwietnia 1950 r. [w:] Państwowe prawo wyznaniowe Polskiej Rzeczypospolitej Ludowej. Wybór tekstów źródlowych, oprac. M. Fąka, Warszawa 1978, s. 27-28; por. J. Żaryn, Kościót a władza ..., s. 258, 314. Należy również zwrócić uwagę, że prace Komisji Mieszanej toczyły się w kontekście nasilenia od 1949 r. antykościelnej polityki państwa, której przejawem były m.in. coraz ostrzejsze nagonki prasowe, także na poszczególnych hierarchów.

20 List prymasa Wyszyńskiego do prał. Tardiniego, Warszawa, 15 czerwca 1950 r., cyt. za: ibidem, s. 315 .

${ }^{21}$ J. Żaryn, Stolica Apostolska wobec Ziem Odzyskanych po II wojnie światowej. Zarys problemu [w:] Kościół katolicki wczoraj i dziś, red. M. Drzonek, K. Kowalczyk, J. Mieczkowski, G. Wej- 
dzenie się w tak niejasnej i niezdecydowanej sprawie Ziem Zachodnich «jakkolwiek zrozumiałe» jest niestosowne"22.

Dla władz komunistycznych punkt trzeci miał więc podwójną wartość: po pierwsze, był zarzewiem nieporozumień między prymasem a Watykanem oraz konfliktował episkopaty Polski i Niemiec; po drugie, dawał skonkretyzowany na papierze powód do „wywoływania do tablicy” Episkopatu w dogodnym dla władz momencie i obwiniania go za niedopełnienie zobowiązania. Sekretarz KW PZPR we Wrocławiu Kazimierz Witaszewski w czasie posiedzenia tamtejszej egzekutywy, 21 kwietnia 1950 roku, wyjaśniał, że poprzez takie sformułowanie punktu trzeciego „wbito klin między duchowieństwem polskim a rewizjonistycznym klerem niemieckim oraz postawiono Watykan w niewygodnym położeniu"23. Jeszcze dobitniej wyraził to na IV Plenum KC PZPR redaktor naczelny „Trybuny Ludu” Leon Kasman:

[...] realizowaliśmy politykę, żeby wbijać klin między szerokie masy katolików w Polsce [...], wykorzystaliśmy rzeczywiste i niewątpliwe zakłopotanie Watykanu umową, która zawiera cały szereg punktów godzących w dotychczasową postawę kleru polskiego [...]. Takie punkty, jak punkt o Ziemiach Zachodnich godzi w Watykan i trzeba być ślepym, żeby tego nie widzieć ${ }^{4}$.

$\mathrm{Z}$ kolei strona kościelna, oceniając realnie sytuację i zdając sobie sprawę $\mathrm{z}$ asekuracyjnego kursu polityki Watykanu, próbowała nakreślić jak najszersze granice własnego działania w kontekście realizacji punktu trzeciego Porozumienia. Na Konferencji Plenarnej Episkopatu, która odbywała się w dniach 21-22 kwietnia 1950 roku w Gnieźnie, ,ustalono, że sprawa ta nadaje się raczej do ustnego przedstawienia w Rzymie"25, oraz zaplanowano poszerzenie składu Komisji Mieszanej o profesorów prawa kanonicznego z Katolickiego Uniwersytetu Lubelskiego: biskupa Piotra Kałwę i księdza Teodora Benscha ${ }^{26}$. W przyjętym zaś komunikacie dla wiernych, dotyczącym zawartego Porozumienia, odnośnie do kwestii administracji kościelnej na tzw. Ziemiach Odzyskanych pojawiły się tylko ogólnikowe stwierdzenia, że „Kościół jednoczy się z całym narodem we wspólnej trosce o poszanowanie naszych dziejowych praw do całości ziemi ojczystej”, a w sprawach jurysdykcji kościelnej papież jest „,najwyższym autorytetem”27.

man, Szczecin 1998, s. 70.

22 AAN, KC PZPR, sygn. 237/V/158, Informacja Dep. V MBP dot. kleru nr 32, Warszawa, 22 maja 1950 r., k. 73; por.: ibidem, Informacja Dep. V MBP dot. kleru nr 33, Warszawa, 26 maja 1950 r., k. 77; ibidem, Informacja Dep. V MBP dot. kleru nr 38, Warszawa, 17 czerwca 1950 r., k. 85.

${ }_{23}$ Protokół nr 15 z posiedzenia egzekutywy KW PZPR, Wrocław, 21 kwietnia 1950 r., cyt. za: Ł. Kamiński, Kościót w dokumentach KW PZPR we Wrocławiu (1949-1956). Rekonesans archiwalny [w:] Represje wobec Kościoła katolickiego na Dolnym Ślasku i Opolszczyźnie 1945-1989, red. S. Bog aczewicz, S. Krzyżanowska, Wrocław 2004, s. 99.

24 AAN, KC PZPR, sygn. III/5, Stenogram IV plenum KC PZPR, Warszawa, 9 maja 1950 r., k. 455.

25 J. Pietrzak, Ks. Karol Milik - administrator apostolski Dolnego Ślaska i władze państwowe w latach 1945-1951 [w:] Ludzie wrocławskiego Kościoła..., s. 39.

26 K. Gruczyński, op. cit., s. 268.

27 Komunikat Episkopatu Polski do wiernych o porozumieniu Episkopatu Polski i Rządu Rzeczypospolitej Polskiej, Gniezno, 22 kwietnia 1950 r. [w:] Komunikaty Konferencji Episkopatu Polski 1945 2000, oprac. J. Żaryn, Poznań 2006, s. 55-56. 
Projektując brzmienie trzeciego punktu, władze państwowe miały więc zaplanowaną strategię wykorzystania tego zapisu jako elementu propagandowej walki z Kościołem, a rozwój wypadków potwierdził, że wydarzenia między kwietniem 1950 a styczniem 1951 roku były kolejnymi elementami - odsłonami zaplanowanej akcji wymierzonej w rozbicie budowanej od pięciu lat organizacji kościelnej na Ziemiach Zachodnich i Północnych i, co więcej, w jedność polskiego Kościoła, co mogło doprowadzić do realnej schizmy.

Okazją do rozpoczęcia wykorzystywania przez władze zapisu punktu trzeciego Porozumienia były przygotowania do zawarcia układu granicznego z Niemiecką Republiką Demokratyczną. Jej proklamowanie w październiku 1949 roku otwierało perspektywę unormowania granicy polsko-niemieckiej. Tak więc władze w Warszawie, już w czasie negocjacji warunków Porozumienia z Kościołem, przygotowywały się do rozmów z NRD dotyczących wspólnej granicy. Punkt trzeci Porozumienia w perspektywie zawarcia układu granicznego stawał się więc dla Episkopatu pułapką, której uruchomienie było tylko kwestią czasu, czyli podpisania układu z NRD. Zobowiązując Episkopat do wystąpienia z prośbą do Watykanu o ustanowienie polskich biskupów na terenie tzw. Ziem Odzyskanych, władze wiedziały, że najbliższe miesiące przyniosą sposobność, by wyegzekwować wywiązanie się polskiego Kościoła $\mathrm{z}$ tego warunku. Tym samym, w obliczu niemożliwości jego spełnienia, dadzą realny powód do propagandowej nagonki na Kościół i umożliwią przystąpienie do realizacji planu przejęcia kontroli nad zarządem administracji apostolskich.

W czasie wizyty w Warszawie na początku czerwca 1950 roku wicepremier NRD Walter Ulbricht zapowiedział zawarcie układu granicznego z Polskąa ${ }^{28}$. Dlatego już trzy tygodnie przed oficjalnym podpisaniem tego układu, 14 czerwca 1950 roku na posiedzeniu Sekretariatu Biura Politycznego KC PZPR ${ }^{29}$, w punkcie drugim porząd$\mathrm{ku}$ obrad m.in. poruszono kwestię rozpoczęcia akcji propagandowej, przygotowującej grunt pod planowaną ingerencję w zarząd kościelny na Ziemiach Zachodnich. Po zreferowaniu przez Franciszka Mazura sytuacji „na odcinku kleru”, w związku $\mathrm{z}$ negatywnym stanowiskiem duchowieństwa $\mathrm{w}$ sprawie akcji zbierania podpisów pod Apelem Sztokholmskim, Sekretariat Biura Politycznego uznał taką postawę za wynik ,presji Watykanu i krajowej reakcji” i tym samym stwierdził, że Episkopat naruszył zawarte dwa miesiące wcześniej Porozumienie ${ }^{30}$. W podpunkcie szóstym zaprotokołowano decyzję, by „przeprowadzić akcję o zlikwidowanie stanu tymczasowości na Ziemiach Odzyskanych" ${ }^{31}$. Pod tą samą datą Bolesław Bierut w swoich prywatnych notatkach zapisał: „rozwinąć kampanię prasową, wychowawczą, propagandową, administracyjną przeciwko podżegaczom wojennym: ogłaszać nazwiska w prasie, demaskować”, wykorzystać „,księży patriotów”, organizować „akcje maso-

28 Zob. T. Marczak, Granica zachodnia w polskiej polityce zagranicznej w latach 1944-1950, Wrocław 1995, s. 552-557.

${ }_{29}$ Uczestniczyli w nim: B. Bierut, J. Berman, J. Cyrankiewicz, H. Minc, F. Mazur, Z. Nowak, E. Ochab, R. Zambrowski oraz A. Zawadzki. AAN, KC PZPR, sygn. V/7, Protokół nr 66 z posiedzenia Sekretariatu BP KC PZPR, Warszawa, 14 czerwca 1950 r., k. 17; także sygn. V/8, k. 93.

30 Ibidem, sygn. V/7, k. 18; także sygn. V/8, k. 94.

31 Ibidem, sygn. V/7, k. 19; także sygn. V/8, k. 95. 
we”, podejmować „kroki administracyjne. Na tym tle atak na reakcyjną część kleru i episkopat pod kątem naruszenia warunków porozumienia" "32.

Rzeczywiście od drugiej połowy czerwca 1950 roku prasa, zarówno ogólnopolska, jak i regionalna, szczególnie ukazująca się na obszarze Ziem Zachodnich i Północnych, wielokrotnie pisała o ,anormalnym stanie tymczasowości” ${ }^{33}$. Redaktor naczelna „Gazety Robotniczej” Irena Tarłowska na posiedzeniu egzekutywy KW PZPR we Wrocławiu 16 czerwca 1950 roku stwierdziła, że „od jutra rozpoczynamy kampanię prasową przeciwko reakcyjnemu klerowi”. Przewidywała m.in. opublikowanie „szeregu ośmieszających felietonów o biskupie [!] Miliku oraz referatów o roli Watykanu w sprawie granic na Odrze i Nysie" ${ }^{34}$. Kampania jednak nie nabrała rozmachu. Natomiast 4 lipca 1950 roku, dwa dni przed podpisaniem układu z NRD, na posiedzeniu Biura Politycznego KC PZPR ${ }^{35}$, w punkcie trzecim porządku obrad, podjęto uchwałę w brzmieniu: ,przygotować list do Episkopatu w sprawie likwidacji tymczasowości instancyj [!] kościelnych na Ziemiach Odzyskanych" ${ }^{\text {36. }}$.

Najprawdopodobniej interwencja władz w kwestie zarządu kościelnego na terenie tzw. Ziem Odzyskanych miała nastąpić bezpośrednio po zawarciu układu granicznego z NRD. Wskazują na to decyzje, jakie zapadły na posiedzeniu Sekretariatu Biura Politycznego KC PZPR 14 czerwca oraz na posiedzeniu Biura Politycznego KC PZPR 4 lipca. Tym samym decyzja o wykonaniu planu usunięcia administratorów apostolskich i przejęciu kontroli nad administracjami poprzez zainstalowanie podporządkowanych władzy państwowej wikariuszy kapitulnych zapadła już pół roku wcześniej, niż miała miejsce jej realizacja.

Po wizycie w Warszawie Ulbrichta zdecydowano o akcji propagandowej, natomiast tuż przed podpisaniem układu granicznego, który kończył rację bytu tymczasowości rozwiązań przyjętych na Ziemiach Zachodnich i tym samym miał stanowić usprawiedliwienie działań zmierzających do usunięcia śladów tej „tymczasowości”, podjęto decyzję o wystosowaniu listu do Episkopatu w sprawie „likwidacji tymczasowości kościelnej na Ziemiach Odzyskanych". List taki nigdy jednak nie powstał albo przynajmniej nigdy nie dotarł do Episkopatu. Wszystko wskazuje na to, że cała akcja „likwidacji tymczasowości” została wstrzymana i powrócono do niej po sześciu miesiącach, realizując według podobnego scenariusza, tzn. wybranie pretekstu usprawiedliwiającego podjęte działania (tym razem podpisanie 27 I 1951 r. we Frankfurcie nad Odrą aktu o wykonaniu wytyczenia granicy z NRD), poprzedzone akcją propagandową, a w przeddzień podpisania aktu frankfurckiego polecenie Biura

32 Ibidem, sygn. XIA/113, Notatki B. Bieruta, 14 czerwca 1950 r., k. 510.

33 B. Fijałkowska, Partia wobec religii i Kościoła w PRL, t. 1, 1944-1955, Olsztyn 1999, s. 109.

34 Protokół nr 23 z posiedzenia egzekutywy KW PZPR, Wrocław, 16 czerwca 1950 r., cyt. za: Ł. Kamiński, op. cit., s. 100 .

35 Udział w posiedzeniu wzięli: B. Bierut, J. Cyrankiewicz, J. Berman, H. Minc, A. Zawadzki, R. Zambrowski, F. Mazur, Z. Nowak, E. Ochab, K. Rokossowski, F. Jóźwiak, A. Rapacki, H. Chełchowski oraz S. Matuszewski. AAN, KC PZPR, sygn. V/6, Protokół nr 39 z posiedzenia BP KC PZPR, Warszawa, 4 lipca 1950 r., k. 299; także sygn. V/4, k. 22.

36 Ibidem, sygn. V/6, k. 300; także sygn. V/4, k. 23. 
Politycznego w sprawie przygotowania już nie listu do Episkopatu, ale oświadczenia Rządu o „likwidacji stanu tymczasowości kościelnej”37.

Hipoteza ta nie była dotąd rozpatrywana w opracowaniach historyków ${ }^{38}$, wymaga więc dalszego potwierdzenia w badaniach archiwalnych, szczególnie pod kątem przyczyn ewentualnego nieprzeprowadzenia akcji w lipcu 1950 roku, być może z powodu niedostatecznego przygotowania lub słabej kampanii propagandowej, co będzie podnoszone także w styczniu 1951 roku $^{39}$. Andrzej Micewski, choć nie podaje źródeł swoich przypuszczeń, pisze że

[...] już wtedy [na przełomie czerwca i lipca 1950 r. - K.K.] zarysowuje się jakaś groźba ze strony rządu w stosunku do administracji kościelnej na Ziemiach Zachodnich. Rząd chciałby wymusić decyzje Stolicy Apostolskiej, nierealne wówczas ze względu na brak traktatu pokojowego lub analogicznych układów międzynarodowych, w sprawach granicznych ${ }^{40}$.

Najprawdopodobniej przypuszczenia te oparte są na informacjach z obrad Konferencji Plenarnej Episkopatu, która miała miejsce 30 czerwca - 1 lipca w Krakowie. Jak wynika z protokołu tej konferencji, biskupi ponownie doszli do wniosku, że sprawa powinna być zreferowana w Rzymie ustnie ${ }^{41}$. Przeczy temu meldunek Departamentu V MBP z 26 czerwca, który zawiera doniesienie odnośnie do obradującej trzy dni wcześniej, 23 czerwca, Komisji Głównej Episkopatu, na której posiedzeniu uchwalono, by „za dwa tygodnie zakomunikować Rządowi, że Episkopat zwrócił się do Watykanu o stabilizację administracji kościelnej na Ziemiach Odzyskanych. List taki podobno już został napisany i ma być w najbliższym czasie wysłany do Rzymu"42. Potwierdzałoby to rzeczywiście napiętą sytuację, jeśli chodzi o losy administracji apostolskich bezpośrednio przed zbliżającym się podpisaniem traktatu z NRD.

W pierwszych dniach lipca ksiądz Karol Milik powiadomił sekretarza Episkopatu, że „należy się spodziewać ataku rządu na administratorów apostolskich na Ziemiach Odzyskanych. Ten «skrzywił się», nie bardzo wierząc w wybuch nowego konfliktu"43. Reakcja biskupa Zygmunta Choromańskiego, najbardziej - zdawałoby się - zorientowanego w sytuacji członka Episkopatu, zaczerpnięta z pamiętnikarskiej

37 Ibidem, sygn. V/16, Protokół nr 49 z posiedzenia BP KC PZPR, Warszawa, 20 stycznia 1951 r., k. 30 .

38 T. Dzwonkow ski, Próby likwidacji administracji apostolskiej i ordynariatu gorzowskiego w latach 1945-1952 [w:] Władze wobec Kościołów i zwiazków wyznaniowych na Środkowym Nadodrzu w latach 1945-1956, red. E. Wojcieszyk, Poznań 2012, s. 51. Autor stawia hipotezę o zamiarze usunięcia administratorów apostolskich po rozmowie Bieruta ze Stalinem w sierpniu 1949 r. i wstrzymaniu akcji w związku ze stanowiskiem nowo powstałej RFN wobec granicy na Odrze i Nysie Łużyckiej.

39 Por. AAN, KC PZPR, sygn. V/9, Protokół nr 62 z posiedzenia Sekretariatu BP KC PZPR, Warszawa, 29 stycznia 1951 r., k. 49; także sygn. V/11, k. 347.

40 A. Micewski, Kardynał Wyszyński, prymas i mąż stanu, Paris 1982, s. 75.

41 J. Pietrzak, op. cit., s. 39.

42 AAN, KC PZPR, sygn. 237/V/158, Informacja Dep. V MBP dot. kleru nr 41, Warszawa, 26 czerwca 1950 r., k. 93. W skład Komisji Głównej Episkopatu w tym czasie wchodzili: prymas S. Wyszyński jako jej przewodniczący, kard. A.S. Sapieha, abp R. Jałbrzykowski, abp E. Baziak, abp W. Dymek, bp Cz. Kaczmarek, bp T. Zakrzewski, bp M. Klepacz i bp Z. Choromański.

43 J. Pietrzak, op. cit., s. 39. 
relacji księdza Milika, wskazywałaby jednak na zaskoczenie Kościoła, gdyby już w lipcu doszło do ingerencji w zarząd kościelny na Ziemiach Zachodnich.

6 lipca 1950 roku w Zgorzelcu premierzy Polski i NRD, Józef Cyrankiewicz i Otto Grotewohl, podpisali układ o przyjaźni i poszanowaniu, który w rozumieniu władz państwowych stawał się argumentem wzmacniającym działania państwa w zakresie nacisków na stronę kościelną, by dopełniła zobowiązania wyrażonego w punkcie trzecim Porozumienia. Układ ze Zgorzelca, zdaniem Rządu polskiego, ostatecznie likwidował wszelkie znamiona dotychczasowej tymczasowości granicy na Odrze i Nysie Łużyckiej i tym samym miał wymusić podjęcie zdecydowanych kroków ze strony władz kościelnych, zmierzających do ostatecznego uregulowania statusu prawnego polskiej administracji kościelnej na tzw. Ziemiach Odzyskanych. Doskonale jednak zdawano sobie sprawę, że Stolica Apostolska, podobnie jak inne państwa Europy Zachodniej, nieuznająca podmiotowości prawnej NRD ani tym bardziej jej prawa do reprezentowania Niemiec na arenie międzynarodowej, nadal będzie podtrzymywać zastrzeżenie, że trwałe zmiany w jurysdykcji kanonicznej Ziem Zachodnich i Północnych będą możliwe do przeprowadzenia dopiero po uznaniu nowej granicy polsko-niemieckiej także przez Republikę Federalną Niemiec ${ }^{44}$. Władze w Warszawie świadomie więc zaogniały sytuację, stawiając w oczach opinii publicznej Episkopat Polski jako stronę niewywiązującą się z punktu trzeciego Porozumienia. W tym celu jeszcze bardziej zintensyfikowano atak propagandowy na rzecz zniesienia tzw. tymczasowości kościelnej na Ziemiach Odzyskanych.

Przeczuwając najprawdopodobniej groźbę bezpośredniej ingerencji państwa w zarząd kościelny na terenie Ziem Zachodnich, Episkopat próbował nie pozostać biernym graczem w planie władz zmierzających do postawienia prymasa i biskupów w patowym położeniu, tzn. $\mathrm{z}$ jednej strony zobowiązanie punktu trzeciego Porozumienia, $\mathrm{z}$ drugiej strony presja wywierana zawartym układem granicznym z NRD, w mniemaniu komunistów ustalającym zachodnią granicę Polski. Odpowiadając na nagonkę propagandową, zarzucającą Kościołowi zwlekanie z wypełnieniem punktu trzeciego Porozumienia, Episkopat przystąpił jednocześnie do „kontrataku”, wystosowując 8 sierpnia 1950 roku list do Rządu ${ }^{45}$, w którym przedstawiono dotychczasowy

44 J. Sikorski, Dążenie władz do kasacji stanu tymczasowości administracji kościelnej na ziemiach zachodnich i pótnocnych Polski ze szczególnym uwzględnieniem ordynariatu gorzowskiego, „Studia Zachodnie" 2005, t. 8, s. 226; S. Markiewicz, Polityka wschodnia Watykanu, Warszawa 1982, s. 56; R. Włodkowski, Usunięcie administratorów apostolskich w 1951 roku jako przykład polityki państwa wobec Kościoła na Ziemiach Zachodnich [w:] Państwo, Kościól, Europa - nowe wyzwania, red. M. Drzonek, J. Mieczkowski, K. Kowalczyk, Szczecin 1999, s. 56.

45 Archiwum Sekretariatu Konferencji Episkopatu Polski w Warszawie (ASKEP), sygn. 06630, List bp. Choromańskiego do Rządu, Warszawa, 8 sierpnia 1950 r., k. 36-37; także AAN, Ministerstwo Administracji Publicznej, sygn. 961, k. 55-58. P. Raina, Kościót w PRL. Kościót katolicki a państwo w świetle dokumentów 1945-1989, t. 1, Lata 1945-59, Poznań 1994, s. 245. Autor błędnie podaje datę 8 lipca. Cz. Osękowski, opierając się na błędnej datacji listu, wysuwa mylne wnioski, jakoby list ten miał być natychmiastową (po dwóch dniach) odpowiedzią na układ zgorzelecki, zob. Cz. Osękowski, Ks. Prymas Stefan Wyszyński wobec stosunków polsko-niemieckich [w:] Stefan kardynat Wyszyński wobec Ziem Zachodnich i Pótnocnych oraz stosunków polsko-niemieckich, red. T. Dzwonkowski, Cz. Osękowski, Warszawa-Poznań-Zielona Góra 2001, s. 26-27. 
stan organizacyjny Kościoła na terenie Ziem Zachodnich i Północnych, punktując zarazem wszelkie utrudnienia, jakie władze państwowe stosują wobec instytucji kościelnych, głównie seminariów i kurii. List rozpoczynał się deklaracją, odwołującą się do punktu trzeciego Porozumienia, zgodnie z którą „Biskupi polscy pragną wystąpić do Stolicy Świętej z prośbą o przemianowanie dotychczasowych Administracji na Ziemiach Odzyskanych na stałe jednostki jurysdykcji kościelnej"46. Była to odpowiedź na propagandowe zarzuty pod adresem Episkopatu, który rzekomo kunktatorsko zapomina o warunkach Porozumienia, tym samym po cichu sprzyjając zachodnioniemieckiemu rewizjonizmowi. W swojej dalszej wymowie podpisany przez biskupa Choromańskiego list był jednoznacznym oskarżeniem władz państwowych o celową politykę materialnego osłabiania i represjonowania Kościoła na terenach administracji apostolskich. Kończył się stwierdzeniem, że:

gdy mamy zabiegać o prawne podstawy organizacji kościelnej na Ziemiach Odzyskanych [...] trzeba stwierdzić i udowodnić, co zrobił dla Kościoła na Ziemiach Odzyskanych Rząd Polski, który domaga się ustabilizowania od Stolicy Apostolskiej stosunków kościelnych na Ziemiach Odzyskanych. Wyrażamy obawę, że wszystkie zaszłe na Ziemiach Odzyskanych fakty, stawiające Kościół w sytuacji bez bytu materialnego, wysoce utrudniają przebieg rozmów na ten temat ${ }^{47}$.

List był nacechowany postawą obronną wobec zarzutów propagandy ostatnich tygodni, stąd podkreślanie związku antykościelnej polityki władz państwowych na Ziemiach Zachodnich z umocowaniem stanowiska Episkopatu Polski w Watykanie jako rzecznika reorganizacji diecezjalnej na tym terenie, której warunkiem koniecznym była trwała baza materialna.

W obecnej sytuacji możemy łatwo spotkać się z zarzutem, że Państwo robi wszystko, aby podciąć podstawy bytu i pracy Kościoła na Ziemiach Odzyskanych, podczas gdy od Kościoła domaga się stabilizacji form zarządu kościelnego. Jednocześnie zaznaczono, że Episkopat Polski oczekuje takiego oświadczenia Rządu w omawianej sprawie, które wzmocniłoby nasze przedłożenie do Stolicy Apostolskiej ${ }^{48}$.

Episkopat rozpoczął więc „typową grę na zwłokę"49. Przyjmując hipotezę o planowaniu ,zniesienia tymczasowości kościelnej na Ziemiach Odzyskanych” już w lipcu 1950 roku i podejrzeniach Episkopatu co do możliwości takiego scenariusza wydarzeń, odważny ton listu mógł być potwierdzeniem tych obaw i swego rodzaju wyraźnym zaznaczeniem własnej argumentacji wobec groźby podjęcia przez władze państwowe jednostronnych działań.

Warto zwrócić uwagę, że oprócz listu, który - jako skierowany do Rządu - nie mógł dotrzeć do opinii publicznej, prymas Wyszyński podjął jednocześnie działania zmierzające do odkłamania propagandowego wizerunku Kościoła niechętnego

46 ASKEP, sygn. 06630, List bp. Choromańskiego do Rządu, Warszawa 8 sierpnia 1950 r., k. 36.

47 Ibidem, k. 37.

48 Ibidem.

49 S. Jankowiak, Ziemie zachodnie i pótnocne w stosunkach państwo - Kościót w Polsce w latach 1945-1956 [w:] Między integracją a komunizmem. Społeczeństwa i Kościoły Europy Środkowej, red. K. Kowalczyk, A. Kubaj, R. Wróblewski, Tuchów 2001, s. 95. 
polskości tzw. Ziem Odzyskanych i w lipcu oraz sierpniu 1950 roku odbył kilka podróży na te tereny, odwiedzając m.in. Wrocław, Zieloną Górę, Gorzów Wielkopolski, Olsztyn i Elbląg ${ }^{50}$. Rząd pozostawił list z 8 sierpnia bez odpowiedzi, a odważny język użytych w nim sformułowań dał komunistom sygnał, że planowana interwencja odnośnie do zarządu kościelnego na Ziemiach Zachodnich wymaga dalszego nasilenia czynników propagandowych.

Drugi ruch ze strony Episkopatu w kwestii odparcia ataków propagandy, zarzucającej Kościołowi prowadzenie antypolskiej polityki na tzw. Ziemiach Odzyskanych, nastąpił po odbytej w dniach 12-13 września 1950 roku Konferencji Plenarnej Episkopatu w Częstochowie, na której przyjęto projekt listu skierowanego do prezydenta Bieruta. W obszernym memoriale, podpisanym przez prymasa Wyszyńskiego i kardynała Sapiehę, kwestii administracji apostolskich poświęcono osobny rozdział. W odróżnieniu od listu z 8 sierpnia teraz, oprócz stonowanych zarzutów, pojawiła się także propozycja łagodzenia sytuacji i szukania, za cenę obopólnych ustępstw, półśrodków w rozwiązaniu stanu tymczasowości. Był to niejako drugi akord gry na zwłokę ze strony Episkopatu, który - w obliczu nasilającej się propagandy i wobec braku wpływu na decyzję Watykanu - odczuwał coraz bardziej ograniczone możliwości działania w kwestii utrzymania dotychczasowego statusu administratorów apostolskich.

Przypomniano, że Episkopat zobowiązał się w Porozumieniu z 14 kwietnia „przedstawić Stolicy Apostolskiej sprawę stabilizacji stosunków kościelnych na terenach zarządzanych przez Administratorów Apostolskich”, ale jednocześnie zaznaczono, że administratorzy ci w spełnianiu swoich funkcji „niewiele się różnią od zwykłych biskupów” i co więcej, stworzyli na podległych sobie terenach „diecezje, które już obecnie wypełniają wszystkie religijno-kościelne obowiązki wobec wiernych" ${ }^{51}$. $\mathrm{W}$ ten sposób próbowano podważyć lansowany coraz bardziej przez propagandę rządową obraz tymczasowości struktur polskiego Kościoła na ziemiach poniemieckich oraz postulat jej likwidacji. Ze strony Episkopatu było to trochę „wycofywanie się rakiem" nie tylko z mocnej nuty listu z 8 sierpnia, ale i z punktu trzeciego Porozumienia. Zdano sobie bowiem sprawę, że władze państwowe realizację tego punktu tak naprawdę upatrują nie w zwróceniu się Episkopatu z prośbą do Stolicy Apostolskiej, ale w spełnieniu tej prośby przez Watykan, co dla każdej ze stron było scenariuszem nierealnym ${ }^{52}$. Stąd w liście z 12 września padło jednoznaczne stwierdzenie, że wspomniane wyżej argumenty potwierdzają „prawdziwą stabilizację życia Kościoła na Ziemiach Odzyskanych, co jest łatwe do stwierdzenia nawet w drodze powierzchownej obserwacji”. Jednym tylko zdaniem uzupełniono, że ,jedynie prawna

50 AAN, UdsW, sygn. 8/1546, List prymasa Wyszyńskiego do ks. Benscha, Warszawa, 8 września 1950 r., k. 1-3; J. Chłosta, Zwiazki Prymasa Polski Stefana kardynała Wyszyńskiego z Warmia [w:] Stefan kardynat Wyszyński..., s. 156-157; M. Romaniuk, Życie, twórczość i postuga Stefana Kardynata Wyszyńskiego Prymasa Tysiaclecia, [t. 1], Warszawa 1994, s. 429-430; A. Mic ew ski, Kardynat Wyszyński..., s. 75.

51 List Episkopatu Polski do prezydenta Bieruta, Częstochowa, 12 września 1950 r. [w:] P. Raina, op. cit., s. 256-257.

52 Por. A. Dudek, op. cit., s. 23. 
strona pozostawiona jest ostatecznej decyzji Stolicy Apostolskiej”"53. Wyraźnie więc Episkopat próbował nakreślić położenie Kościoła na Ziemiach Zachodnich w świetle łagodzącym rządową presję na potrzebę zniesienia tzw. tymczasowości tamtejszych struktur kościelnych.

List w części poświęconej zagadnieniu administratorów apostolskich kończył się deklaracją, że „Episkopat jest gotów przedłożyć tę sprawę Stolicy Apostolskiej”. Co więcej, relacjonowano nawet, że list do Ojca Świętego w tej sprawie jest w przygotowaniu, ale Episkopat „,napotkał na poważne trudności, nie bez znaczenia dla sprawy" ${ }^{4}$. Ciężko rozstrzygnąć, czy autorzy listu, pisząc o „poważnych trudnościach", mieli na myśli przytoczone w zakończeniu konkretne działania władz państwowych ostatnich tygodni (głównie chodziło o utrudnianie funkcjonowania seminariów duchownych w Olsztynie, Opolu i Wrocławiu), czy też kwestie, które nie zostały wyartykułowane w liście (np. wynikające z rozeznania sytuacji w Watykanie czy też działań Episkopatu niemieckiego). Memoriał prymasa Wyszyńskiego i kardynała Sapiehy, podobnie jak list z 8 sierpnia, pozostał bez odpowiedzi ze strony władz państwowych ${ }^{55}$.

Biskup Choromański 19 września, w imieniu Episkopatu, zwrócił się do Rządu z propozycją wspólnych rozmów dotyczących „trudności wykonywania Porozumienia” oraz ,perspektywy dalszej współpracy”, przedstawiając jednocześnie skład delegacji kościelnej i prosząc o desygnowanie odpowiednich przedstawicieli Rządu do „omówienia tych spraw kolegialnie" ${ }^{56}$. Ostatnie bowiem posiedzenie Komisji Mieszanej miało miejsce 5 sierpnia $1950 \mathrm{roku}^{57}$. Strona rządowa nie przyjęła tej propozycji. Co więcej, przez następne tygodnie władze coraz wyraźniej zajmowały stanowisko ignorowania jakichkolwiek ruchów ze strony Episkopatu i niepodejmowania rozmów ani nieprzyjmowania korespondencji ${ }^{58}$. Być może wykorzystywano ten czas na ponowne, tym razem dokładniejsze, przygotowanie planu usunięcia administratorów apostolskich, poprzedzone przemyślaną kampanią propagandową. Bowiem niespodziewanie dla Episkopatu, 23 października 1950 roku, władze państwowe przystąpiły do otwartego ataku, wykorzystując kwestię administracji kościelnej na Ziemiach Zachodnich i Północnych. Tego dnia dyrektor Urzędu ds. Wyznań Antoni Bida odczytał i wręczył sekretarzowi Episkopatu pismo, w którym w sposób jednoznaczny pobrzmiewała groźba interwencji państwa w sprawy zarządu kościelnego tzw. Ziem Odzyskanych.

53 List Episkopatu Polski do prezydenta Bieruta, Częstochowa, 12 września 1950 r. [w:] P. Raina, op. cit., s. 257.

54 Ibidem.

55 J. Zabłocki, Prymas Stefan Wyszyński. Opór i zwycięstwo 1948-1956, Warszawa 2002, s. 113. 15 września dyrektor UdsW A. Bida oświadczył bp. Choromańskiemu, że odpowiedź na jego list z 8 sierpnia nie zostanie udzielona. AAN, UdsW, sygn. 149/16, List bp. Choromańskiego do Rządu, Warszawa, 2 listopada 1950 r., k. 84.

56 List bp. Choromańskiego do Rządu, Warszawa, 19 września 1950 r. [w:] P. Raina, op. cit., s. 262.

57 A. Micewski, Kardynał Wyszyński..., s. 75.

58 Zob. List bp. Choromańskiego do dyr. Bidy, Warszawa, 19 października 1950 r. [w:] P. Raina, op. cit., s. 264-265. 
List był zredagowany przez ścisłe kierownictwo KC PZPR i w swoim założeniu miał inicjować przygotowania do usunięcia administratorów apostolskich ${ }^{59}$. Jego tekst 19 października został rozesłany na polecenie Jakuba Bermana do członków Sekretariatu Biura Politycznego „z prośbą o przesłanie uwag w ciągu dnia jutrzejszego" ${ }^{\circ 0}$. Najprawdopodobniej list ten był spóźnioną realizacją analizowanego powyżej postanowienia Biura Politycznego KC PZPR z 4 lipca ${ }^{61}$. Jeżeli tak, raz jeszcze pojawia się pytanie o przyczynę prawie czteromiesięcznego opóźnienia wykonania przygotowanego wcześniej planu, tym bardziej że w prywatnych notatkach Bieruta pod datą „,14.VI.50”, w podpunkcie „sprawa kleru” pojawia się zapis: „Główny taran [?]: Ziemie Zachodnie [podkreślenie w tekście - K.K.] - opublikować zwrócenie się Urzędu Wyzn[ań - K.K.]"62; jednak do 23 października nie można wskazać, by podjęto działania w takiej formie.

Dynamiczny rozwój wydarzeń między 23 października 1950 a 26 stycznia 1951 roku pozwala wnioskować, że decyzja o formie i przybliżonym czasie realizacji akcji „B” musiała zapaść przed wystosowaniem listu ministra Bidy. List ten bowiem okazał się być początkiem ostatniej fazy bezpośrednich przygotowań do ingerencji w zarząd kościelny na Ziemiach Zachodnich.

Bez względu na to, czy odnośnie do lipca 1950 roku postawimy hipotezę ,większą" - o pierwotnym planowaniu realizacji całej akcji „B” - czy też hipotezę „mniejszą" - o wcześniejszych planach jedynie listu ministra Bidy - aktualne pozostają pytania o przyczyny opóźnienia tych działań. Zaprezentowane symptomy wskazują bowiem na analogię sytuacji na przełomie czerwca i lipca 1950 oraz w styczniu 1951 roku i intensyfikację w tym czasie działań ukierunkowanych na odsunięcie administratorów apostolskich od sprawowanych funkcji. Zagadnienie planu przejęcia kontroli nad organizacją Kościoła na Ziemiach Zachodnich i Północnych czy nawet samo wydarzenie usunięcia administratorów apostolskich w dotychczasowej historiografii nie było przedmiotem ujęcia monograficznego.

59 ASKEP, sygn. 06630, List dyr. Bidy do bp. Choromańskiego, Warszawa, 23 października 1950 r., k. 38-39; także: AAN, UdsW, sygn. 5a/8, k. 19, 27; sygn. 149/16, k. 87; ibidem, KC PZPR, sygn. 237/V1a/32, k. 2; sygn. 237/V/103, k. 13; sygn. 237/V/167, k. 60, 62 (projekty listu); por. T. Dzwonkowski, op. cit., s. 53 .

${ }^{60}$ AAN, KC PZPR, sygn. 237/V/167, Pismo Kancelarii Sekretariatu KC do członków Sekretariatu BP KC PZPR, Warszawa, 19 października 1950 r., k. 61.

${ }_{61}$ Ibidem, sygn. V/6, Protokół nr 39 z posiedzenia BP KC PZPR, Warszawa, 4 lipca 1950 r., k. 300; także sygn. V/4, k. 23; por. B. Fijałkowska, op. cit., s. 109.

62 AAN, KC PZPR, sygn. XIA/113, Notatki B. Bieruta, 14 czerwca 1950 r., k. 509. Na następnej stronie, w dalszej części notatki pod tą samą datą, powtórzony jest zapis: „Ziemie Zachodnie: oświadczenie Urzędu Wyznań”. Ibidem, k. 510. 


\title{
BIBLIOGRAFIA
}

\author{
Archiwalia
}

\section{Archiwum Akt Nowych w Warszawie}

Akta Antoniego Bidy, sygn. 484/13.

Komitet Centralny Polskiej Zjednoczonej Partii Robotniczej, sygn.: III/5; V/4; V/6; V/7; V/8; V/9; V/11; V/16; 237/V/103; 237/V/158; 237/V/162; 237/V/167; 237/V-1a/32; XIA/113. Ministerstwo Administracji Publicznej, sygn. 961.

Urząd ds. Wyznań, sygn.: 5a/8; 8/1; 8/1546; 149/16.

\section{Archiwum Sekretariatu Konferencji Episkopatu Polski w Warszawie}

sygn. 06630 [Proces likwidacji tymczasowości stanowisk kościelnych na Ziemiach Odzyskanych 1949-1967].

\section{Biuro Udostępniania i Archiwizacji Dokumentów IPN w Warszawie}

sygn.: 01283/790 [Kościół na Ziemiach Odzyskanych 1951-1953]; 01332/4 [Materiały dot. księży autochtonów na Ziemiach Zachodnich i Północnych].

\section{Oddziałowe Biuro Udostępniania i Archiwizacji Dokumentów IPN w Katowicach}

sygn. S38/02/Zk [Akta śledztwa ws. represji wobec sióstr zakonnych w ramach akcji X2].

\section{Źródła drukowane}

Instrukcje, wytyczne, okólniki dyrektor Departamentu V MBP dotyczace działań przeciwko Kościołowi katolickiemu w latach 1945-1953, wybór i oprac. A. Dziurok, J. Marecki, F. Musiał, Kraków-Katowice 2012.

Komunikaty Konferencji Episkopatu Polski 1945-2000, oprac. J. Żaryn, Poznań 2006.

Metody pracy operacyjnej aparatu bezpieczeństwa wobec Kościołów i związków wyznaniowych 1945-1989, red. A. Dziurok, Warszawa 2004.

Państwowe prawo wyznaniowe Polskiej Rzeczypospolitej Ludowej. Wybór tekstów źródtowych, oprac. M. Fąka, Warszawa 1978.

Raina P., Kościót w PRL. Kościót katolicki a państwo w świetle dokumentów 1945-1989, t. 1, Lata 1945-59, Poznań 1994.

Wyszyński S., Pro memoria. Zapiski z lat 1948-1949 i 1952-1953, Warszawa 2007.

\section{Monografie i artykuły}

Chłosta J., Zwiazki Prymasa Polski Stefana kardynała Wyszyńskiego z Warmia [w:] Stefan kardynat Wyszyński wobec Ziem Zachodnich i Pótnocnych oraz stosunków polsko-niemieckich, red. T. Dzwonkowski, Cz. Osękowski, Warszawa-Poznań-Zielona Góra 2001, s. 156-164.

Dudek A., Państwo i Kościół w Polsce 1945-1970, Kraków 1995. 
Dziurok A., Wstęp [w:] Metody pracy operacyjnej aparatu bezpieczeństwa wobec Kościotów i związków wyznaniowych 1945-1989, red. A. Dziurok, Warszawa 2004, s. 17-74.

Dzwonkowski T., Próby likwidacji administracji apostolskiej i ordynariatu gorzowskiego w latach 1945-1952 [w:] Władze wobec Kościołów i związów wyznaniowych na Środkowym Nadodrzu w latach 1945-1956, red. E. Wojcieszyk, Poznań 2012, s. 45-72.

Fijałkowska B., Partia wobec religii i Kościoła w PRL, t. 1, 1944-1955, Olsztyn 1999.

Grajewski A., Chronologia i historyczne uwarunkowania represji wobec duchowieństwa katolickiego w krajach Europy Środkowej [w:] Represje wobec duchowieństwa Kościotów chrześcijańskich $w$ okresie stalinowskim $w$ krajach bylego bloku wschodniego, red. J. Myszor, A. Dziurok, Katowice 2004, s. 15-34.

Grajewski A., Wygnanie, Katowice 1995.

Gruczyński K., Biskup Michał Klepacz 1893-1967, Łódź 1993.

Gryz R., Państwo a Kościót w Polsce 1945-1956 na przykładzie województwa kieleckiego, Kraków 1999.

Hanich A., Likwidacja „,stanu tymczasowości administracji kościelnej” na Śląsku Opolskim przez władze komunistyczne w 1951 r., „Forum Duszpasterskie. Biuletyn Pastoralny” 2003, nr 52, s. 38-54.

Jankowiak S., Ziemie zachodnie i pótnocne w stosunkach państwo - Kościół w Polsce w latach 1945-1956 [w:] Między integracja a komunizmem. Społeczeństwa i Kościoły Europy Środkowej, red. K. Kowalczyk, A. Kubaj, R. Wróblewski, Tuchów 2001, s. 88-96.

Kamiński Ł., Kościół w dokumentach KW PZPR we Wrocławiu (1949-1956). Rekonesans archiwalny [w:] Represje wobec Kościoła katolickiego na Dolnym Ślasku i Opolszczyźnie 1945-1989, red. S. Bogaczewicz, S. Krzyżanowska, Wrocław 2004, s. 97-104.

Kopiec J., Kościót katolicki na Śląsku Opolskim w totalitarnym państwie (1945-1989) [w:] Kościót opolski w PRL, red. M. Worbs, Opole 2007, s. 17-104.

Kopiec J., Wroctawski epizod w życiu biskupa Henryka Grzondziela w latach 1945-1953 [w:] Ludzie wrocławskiego Kościoła po II wojnie światowej, red. I. Dec, K. Matwijowski, J. Pater, Wrocław 2005, s. 46-51.

Marczak T., Granica zachodnia w polskiej polityce zagranicznej w latach 1944-1950, Wrocław 1995.

Markiewicz S., Polityka wschodnia Watykanu, Warszawa 1982.

Micewski A., Kardynat Wyszyński, prymas i mąż stanu, Paris 1982.

Micewski A., Kościót - państwo, Warszawa 1994.

Osękowski Cz., Ks. Prymas Stefan Wyszyński wobec stosunków polsko-niemieckich [w:] Stefan kardynat Wyszyński wobec Ziem Zachodnich i Północnych oraz stosunków polsko-niemieckich, red. T. Dzwonkowski, Cz. Osękowski, Warszawa-Poznań-Zielona Góra 2001, s. 20-32.

Pietrzak J., Ks. Karol Milik - administrator apostolski Dolnego Ślaska i władze państwowe w latach 1945-1951 [w:] Ludzie wrocławskiego Kościoła po II wojnie światowej, red. I. Dec, K. Matwijowski, J. Pater, Wrocław 2005, s. 29-45.

Romaniuk M., Życie, twórczość i posługa Stefana Kardynała Wyszyńskiego Prymasa Tysiaclecia, [t. 1], Warszawa 1994.

Sikorski J., Dążenie władz do kasacji stanu tymczasowości administracji kościelnej na ziemiach zachodnich i pótnocnych Polski ze szczególnym uwzględnieniem ordynariatu gorzowskiego, „Studia Zachodnie” 2005, t. 8, s. 223-238.

Sitek A., Porwali Go z miejsca i wyrzucili (Łk 4, 29). Trzy wypędzenia, Opole 2004.

Stanaszek B., Usunać biskupa! Władze PRL wobec ordynariusza diecezji sandomierskiej Jana Kantego Lorka, Sandomierz 2004. 
Stanaszek B., ,Wrogo ustosunkowany do naszego państwa”. Biskup Piotr Gołębiowski $w$ dokumentach komunistycznej bezpieki i władz wyznaniowych, Sandomierz 2006.

Swastek J., Rzadcy archidiecezji wrocławskiej w latach 1945-1995, Wrocław 1998.

Szetelnicki W., Kapituła metropolitalna we Wrocławiu $w$ latach 1952-1993, Wrocław 1994.

Śledzianowski J., Ksiądz Czesław Kaczmarek biskup kielecki 1895-1963, Kielce 1991.

Włodkowski R., Usunięcie administratorów apostolskich w 1951 roku jako przykład polityki państwa wobec Kościoła na Ziemiach Zachodnich [w:] Państwo, Kościót, Europa - nowe wyzwania, red. M. Drzonek, J. Mieczkowski, K. Kowalczyk, Szczecin 1999, s. 53-60.

Zabłocki J., Prymas Stefan Wyszyński. Opór i zwycięstwo 1948-1956, Warszawa 2002.

Żaryn J., Kościół a władza w Polsce (1945-1950), Warszawa 1997.

Żaryn J., Stolica Apostolska wobec Ziem Odzyskanych po II wojnie światowej. Zarys problemu [w:] Kościól katolicki wczoraj i dziś, red. M. Drzonek, K. Kowalczyk, J. Mieczkowski, G. Wejman, Szczecin 1998, s. 61-73.

Żurek J., Ruch „,księży patriotów” w województwie katowickim w latach 1949-1956, Warszawa-Katowice 2009. 